I TATTI STUDIES IN

ITALIAN RENAISSANCE HISTORY

\title{
标
}

Published in collaboration with I Tatti

The Harvard University Center for Italian Renaissance Studies

Florence, Italy 


\section{GENERAL EDITOR}

\section{Kate Lowe}




\title{
FORGOTTEN HEALERS
}

Women and the Pursuit of Health in Late Renaissance Italy

\section{SHARON T. STROCCHIA}

\author{
III \\ Harvard University Press \\ Cambridge, Massachusetts \\ London, England \\ 2019
}


Copyright (c) 2019 by the President and Fellows of Harvard College ALL RIGHTS RESERVED

Printed in the United States of America

First printing

Jacket design: Tim Jones

Jacket artwork: Portrait of an unknown Florentine nun pharmacist by Alessandro

Gherardini, 1723, courtesy of the Museum of Fine Arts, Budapest.

9780674243453 (EPUB)

9780674243460 (MOBI)

$9780674243446(\mathrm{PDF})$

The Library of Congress has cataloged the printed edition as follows:

Names: Strocchia, Sharon T., 1951- author.

Title: Forgotten healers : women and the pursuit of health in Late Renaissance Italy /

Sharon T. Strocchia.

Other titles: I Tatti studies in Italian Renaissance history.

Description: Cambridge, Massachusetts : Harvard University Press, 2019. |

Series: I Tatti studies in Italian Renaissance history | Includes bibliographical references and index.

Identifiers: LCCN 2019012378 | ISBN 9780674241749

Subjects: LCSH: Women healers-Italy-History-16th century. | Women healers-ItalyHistory-17th century. | Women in medicine-Italy-History-16th century. | Women in medicine-Italy-History-17th century. | Medical care-Italy-History16th century. | Medical care-Italy-History-17th century. | Medicine-ItalyHistory-16th century. | Medicine-Italy-History-17th century.

Classification: LCC R517 .S77 2019 | DDC 610.94509/031-dc23

LC record available at https://lccn.loc.gov/2019012378 
In memory of

STELLA STROCCHIA

Mother, teacher, caregiver 
